UDC 539.43: 621.64

O.O. Larin, DSc, Prof., K.E. Potopalska

National Technical University “Kharkiv Polytechnic Institute”, 2 Kyrpychova Str., Kharkiv, Ukraine, 61002;

e-mail: ks.potopalskaya@gmail.com

\title{
ESTIMATION OF RESIDUAL STRENGTH OF PIPELINE'S ELBOW WITH VOLUMETRIC CORROSION DEFECT, WHICH IS DEVELOPING
}

О.О. Ларін, К.Є. Потопальська. Оцінка залишкової міцності криволінійної ділянки трубопроводу $з$ корозійним об'ємним дефектом, що розвивається. Магістральні трубопроводи є найпоширенішим засобом транспортування нафтопродуктів або газу, їх призначено для тривалого використання. Під час експлуатації внаслідок дії агресивного середовища на поверхні трубопроводу можуть виникати та розвиватися поверхневі дефекти, які певною мірою впливають на міцність трубопроводу. Дослідження проводилося 3 метою оцінки залишкової міцності коліна трубопроводу з об'ємним дефектом, розвиток якого моделюється у часі. Оцінку характеристик напружено-деформованого стану пошкодженого елементу коліна трубопроводу проводили в рамках сучасних засобів комп'ютерного моделювання з використанням методу скінчених елементів (МСЕ). Корозійне пошкодження моделювали явно як об’ємний дефект на зовнішній поверхні коліна трубопроводу. На основі проведеного дослідження отримано результати 3 оцінки залишкової міцності магістрального трубопроводу зі зростаючим поверхневим дефектом в період експлуатації від 10 до 45 років. Визначено зони, в яких з'являється локалізація максимальних еквівалентних напружень та, відповідно, пластичних деформацій в залежності від розміру пошкодження. Опираючись на отримані результати можна зазначити, що в період експлуатації від 37 років трубопровід з відповідним дефектом не витримує можливе максимальне навантаження.

Ключові слова: магістральний трубопровід, корозія, пошкодження, НДС, залишкова міцність

O.O. Larin, K.E. Potopalska. Estimation of residual strength of pipeline's elbow with volumetric corrosion defect, which is developing. Pipelines are used as one of the most practical and low cost methods for transmission of different liquid petroleum products and gases. Damage on the pipeline is capable to appear during operation due to the accumulation of fatigue and arising of corrosion. The Aim is estimation the residual strength of pipeline's elbow with volumetric surface defect development of which is modeled in time. Deformed state assessment of damaged elbow of pipelines was held in the framework of computer modeling by using finite-element method (FEM). Corrosion damage modeled explicitly as volumetric defect on the outside of the knee pipeline. Based on the results of the study the assessment of the residual strength of pipeline with increasing surface defects in operation from 10 to 45 years has been obtained. Besides, the areas in which there is localization of maximum equivalent stresses and respectively plastic deformation depending on the size of damage were defined. By obtained results may be noted that after 37 years of operation the pipelines with the corresponding defect on surface cannot withstand the maximum load.

Keywords: pipelines, corrosion, damage, stress-strain state, residual strength

Introduction. Pipelines are one of the most practical and economical methods for the transportation of various liquid petroleum products and gases. Damages of the pipeline that arise during prolonged operation can appear because of the accumulation of fatigue and the occurrence of corrosion on the surface of the structural elements. Late detection of such damage can lead to dangerous emergencies, causes environmental disasters, pollution as well as substantial consumer losses and a threat to human life. Warning respective events by conducting timely maintenance and repair is a very important task.

The causes of corrosion defects and the peculiarities of their growth in structural elements are of interest to engineers and researchers in the field of analysis and prediction of the initiation of corrosion, as well as the modeling of its development. Questions of the study of the causes of the corrosion are in the competence of physical chemistry and materials science. In this case, the problems of determining the technological means for increasing the stability of the construction material to oxidation or other chemical reactions are considered.

The process of the development of corrosion damage also is paid a lot of attention [1-3]. Of course, in these works great attention is paid to experimental research on the growth of corrosion damage, to analyze the rate of growth, as well as the influence of external factors on it [3].

DOI: ......

(C) 2017 The Authors. This is an open access article under the CC BY license (http://creativecommons.org/licenses/by/4.0/). 
Current works on mathematical modeling of the corrosion growth process that can be used to predict reliability and to assess the residual strength of already damaged structures are also relevant.

In modern studies, the strength and reliability of the design are often estimated using explicit modeling of corrosion damage [4-15], which is usually carried out in software complexes, followed by the use of the finite element method (FEM).

This approach allows numerically investigate the changes of the stress-strain state (SSS) of the pipeline with defects of various shapes and in different places of construction. The most famous literature in the study focuses on the assessment of the residual strength of pipelines with corrosion defects in its straight parts [4-15].

The stress condition of the pipeline's elbow with volumetric corrosion defects is analyzed and is shown that corrosion damage on the curvilinear part of the pipeline leads to a higher concentration of stress $[13,14]$.

The purpose and tasks. The purpose of the work is to study the stress-strain state of the elbow of the pipeline, taking into account the development of the volumetric corrosion defect in time on the outer curvilinear surface of the design.

To achieve the goal we need to solve the following tasks:

To construct a parametric model of the elbow of a pipeline with a volumetric corrosion defect on the surface, taking into account changes in its geometry in time.

Explore the impact of the defect on the stress state of the pipeline and estimate its residual strength.

The object of the study is the development of a localized corrosion defect on the surface of the curvilinear part of the main pipeline.

Materials and methods. The assessment of the characteristics of the SSS damaged element of structures was carried out within the framework of modern computer simulation tools using FEM. Corrosion damage was clearly modeled as a volumetric defect on the outer surface of the elbow of the pipeline.

Modeling of pipeline. The fragment of the pipeline's elbow is modeled taking into account the curvilinear geometry, material properties and loads that conform to the ASME B31G standard. The model is composed of toroidal and cylindrical parts.

The following values of the construction dimensions were chosen for calculation: the outer radius of the pipeline $D=508 \mathrm{~mm}$; wall thickness $h=12,5 \mathrm{~mm}$; the length of the investigated part of the pipeline $l=1.5 \mathrm{~m}$ (according to the X42 type pipeline).

The model is composed of toroidal and cylindrical parts. The following values of the design dimensions were chosen for calculation: the outer radius of the pipeline $D=508 \mathrm{~mm}$; wall thickness $h=12,5 \mathrm{~mm}$; The length of the investigated part of the pipeline is $l=1.5 \mathrm{~m}$ (according to the X42 type pipeline). The length of the straight section of the pipe was chosen a posteriori after a series of previous tests, when the boundary effects in the model do not affect the deformed state in the pipe section under study. The material is steel, the properties of which are given in Table 1.

Table 1

Properties of pipeline material

\begin{tabular}{c|c|c|c|c}
\hline Parametr & $\begin{array}{c}\text { Modulus of elastici- } \\
\text { ty }\end{array}$ & Poisson's coefficient & $\begin{array}{c}\text { The boundary of } \\
\text { fluidity }\end{array}$ & Boundary strength \\
\hline Marking & $E, \mathrm{GPa}$ & $N$ & $\sigma_{\mathrm{T}}, \mathrm{MPa}$ & $\sigma_{\mathrm{B}}, \mathrm{MPa}$ \\
\hline Value & 205 & 0.3 & 290 & 430 \\
\hline
\end{tabular}

For the steel, the plastic area was described using a reinforcement function that consisted of eight points (Fig. 1).

The pipeline area is loaded with internal pressure $\mathrm{P}$ and fixed at the edges. For such pipelines, the nominal (working) pressure is 3MPa. It should also be noted that when operating with a certain frequency it is possible to include and exclude the supply of substance to the pipeline. 


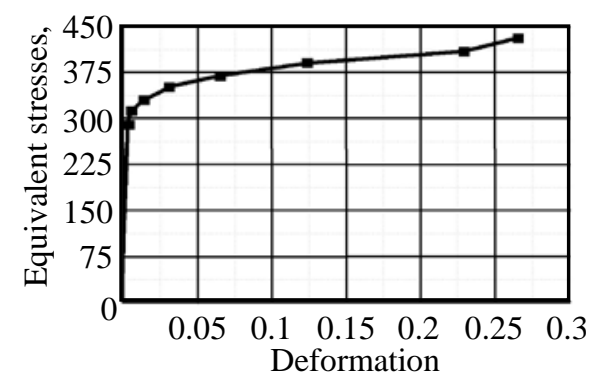

Fig. 1. Plastic area for steel

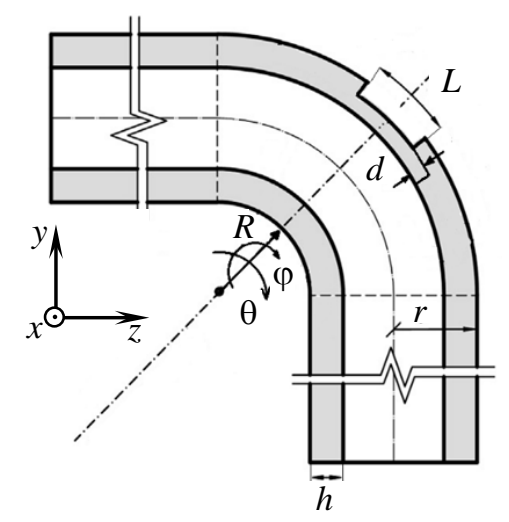

Fig. 2. Sketch of the calculation model

Table 2

Change in internal pressure

\begin{tabular}{c|c|c|c|c|c}
\hline Location area & Typical value & LC1 & LC2 & LC3 & LC4 \\
\hline Max pressure, $\mathrm{MPa}$ & 6 & 12.8 & 10.6 & 8.6 & 7.1 \\
\hline
\end{tabular}

At the same time, the value of internal pressure can be higher than working pressure. The level of maximum load depends on the location of the pipeline and, according to ASME B31.8 (2003), may vary from 6 to $12.8 \mathrm{MPa}$ (Table 2).

Modeling of surface defect. Volumetric surface defect is modeled in the center of the outer surface of the pipeline's elbow. A defect in the form of a parallelepiped with rounded borders was chosen for the study.

Since the defect is located on the bend of the pipe, the sketch was designed in the local toroidal coordinate system, which depends on the radius of the pipeline's elbow $r$. Geometric parameters such as length $L$, width $W$ and depth $d$ are given parametric. This allows you to automatically rebuild the model depending on the size. The draft of a faulty piping elbow is shown in Fig. 2.

The exact dimensions of the defect depend on the current state of its development. From literary data and practice of pipelines exploitation, it is known that over five years the damage of corrosive type occurs on the surface of the pipeline. Over time, the indicated damage increases.

It is proposed to use phenomenological data and models for the average increase in the size of corrosion damage over time. In this way, we will receive calculation models with a defect of a certain level of development and study the residual durability of the pipeline at a certain time of its operation.

From the analysis of well-known studies, it can be summarized that, when defining the growth of defects, linear or nonlinear methods are usually used to determine the geometrical parameters of the damage. After comparing the results of numerical and experimental studies, it can be noted that the linear model of growth of corrosion damage gives incorrect results for failures, namely either overestimates or underestimates the pipeline's resource. Therefore, in the numerical study of the growth of corrosion damage, it is necessary to use nonlinear approaches.

It is proposed to take into account the growth of the defect in the form of a power function, which links the operating time and the average value of the maximum depth of the defect $\left(d_{m}(t)\right)$ [1].

$$
d_{m}(t)=k\left(t-t_{0}\right)^{\alpha},
$$

where $t_{0}$ - time of appearance of corrosive damage;

$\alpha$ and $k$ - the indicators of the kinetics of damage growth, which in most studies are considered as constant (varying from 0.3 to 1 ).

The parameters $\alpha$ and $k$ have been determined, which equal 0.73 and 0.5 respectively [1]. With the use of (1) a change in the average value of the overall dimensions is determinated: depth in Fig. 3, a and length and width in Fig. 3, $b$.

The function of the growth of the defect length has the same appearance, but with other parameters $\alpha$ and $k$. From previous studies, it is known that the length of the defect in the longitudinal direction is changing faster than in the transverse. Therefore, in this work, the width of the defect depends on the change in length and is set proportionally as 0.56 from the length of the defect.

Finite-element model. FEM was used to determine the SSS of the curvilinear part of the pipeline. In the calculations, a quarter of the model was used, which takes into account the pipeline's symmetry. When creating a grid, the features of the model were taken into account. 

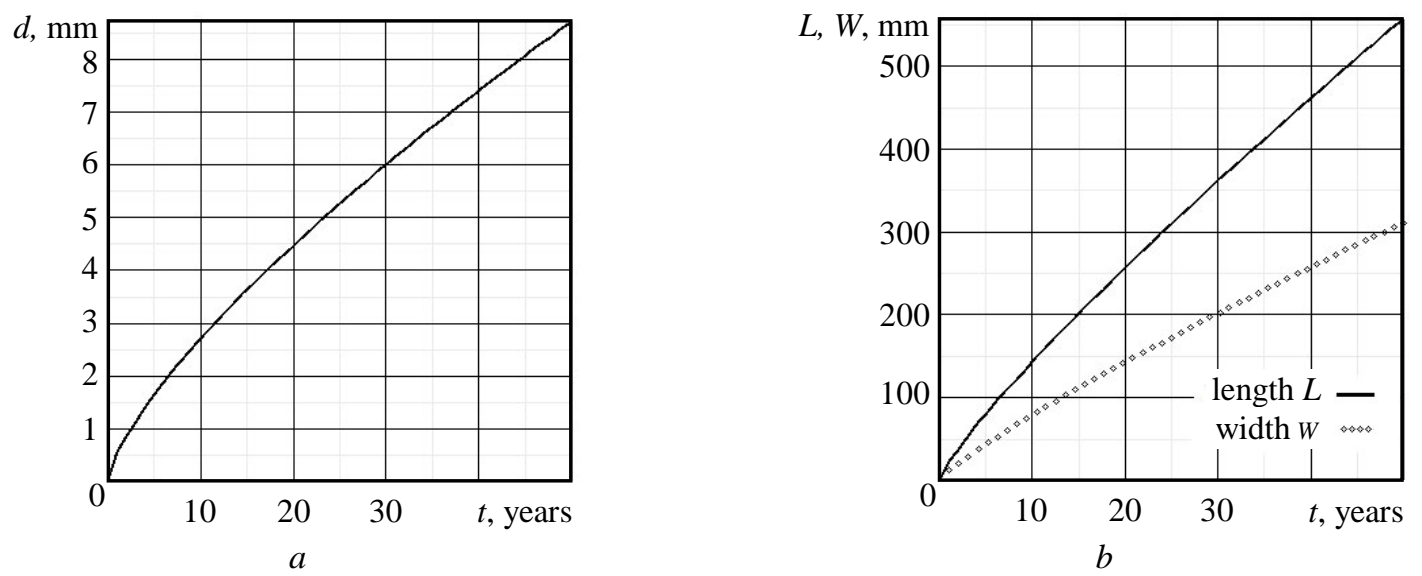

Fig. 3. Graph of changes of defect's depth (a), length and width (b) in time

The size of the element gradually decreases when approaching the damaged zone. Four elements are specified for thickness damage. On undamaged sections of the pipeline, an ordered hexagonal grid was constructed, in the defect zone the tetrahedral grid was build. An isoparametric finite element with 8 nodes and 3 degrees of freedom in the node was used. Grid of the model is shown in Fig. 4.

Research results. The results of a series of calculations of the pipeline's elbow with different defect sizes are presented in accordance with geometrical parameters that correspond to different lifetimes of the damaged pipeline (period from 10 to 45 years).

Separate calculation of the undamaged area of the pipeline's elbow at different values of internal pressure. Fig. 5

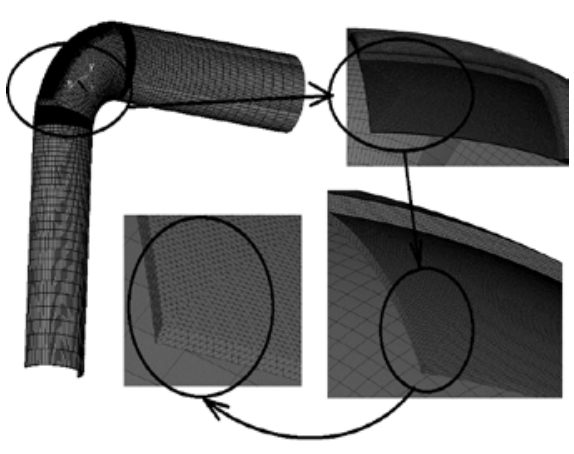

Fig. 4. Grid of the quarter of the pipeline's elbow shows a change in the Mises criterion equivalents.

It was found that the maximum equivalent stresses in this case arise in the zone of greatest curvature of the knee. At nominal pressure, we have a threefold safety margin to the boundary of fluidity. With possible increase in pressure as typical as well as in LC4 area, we have a double safety margin reserve. For the greatest possible cases of working pressure (LC1), the stress reaches the boundary of fluidity, but the strength is still maintained.

In the analysis of a defective construction after 10 years (Fig. 6) of operation, it was found that a defect of this size does not have a significant effect on the construction SSS, and the zone of maximum stress is still the same as in the pipeline without damage. The load, in which plastic deformation occurs, is the same as when the undamaged elbow of the pipeline is reduced by $10 \%$.

The analysis of the SSS of defective pipeline after 30 years is shown in Fig. 7. The maximum stress equivalents are formed in the longitudinal direction of damage area. The load, in which plastic deformation occurs, has decreased by $45 \%$ relative to the value of internal pressure during operation for 10 years.

The analysis of the SSS of the damaged section of the curvilinear part of the pipeline showed that the maximum equivalent stresses are observed in the longitudinal direction of the defect during 42 years of operation. However, the study revealed that with a sufficiently large size of damage, since 45 years of operation, the zone of localization of the maximum equivalent stresses is changing. Fig. 8 shows the distribution of equivalent stress in the case of plastic deformation in a defective pipeline after operation for $42(a)$ and $45(b)$ years. 


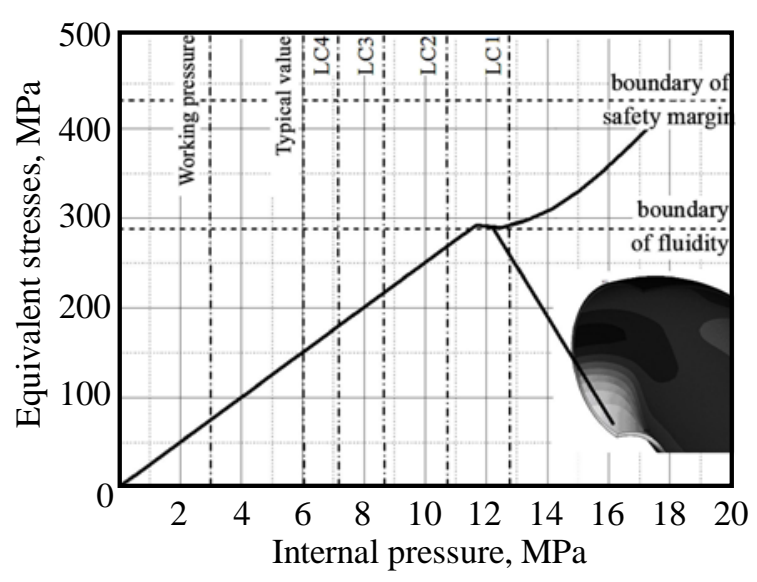

Fig. 5. Change in equivalent stresses in the undamaged pipeline's elbow at different values of internal pressure

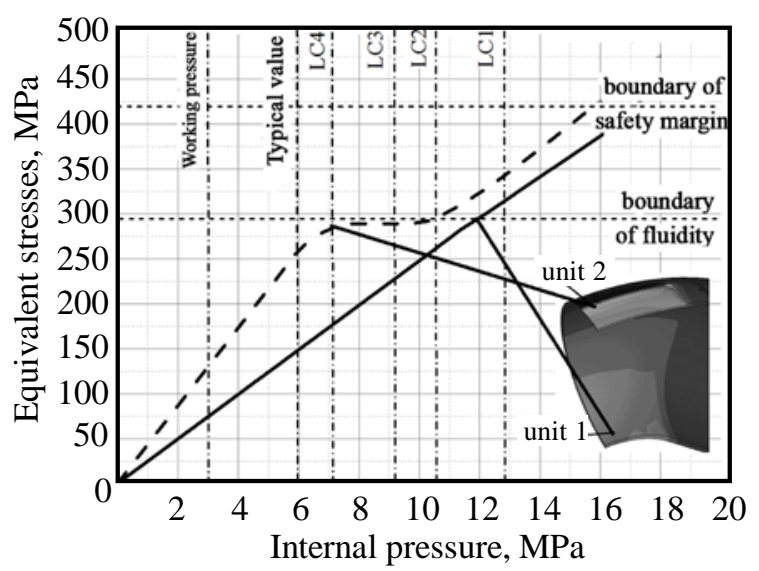

Fig. 7. Change of equivalent stresses in the elbow of a defective pipeline after 30 years of operation at different values of internal pressure

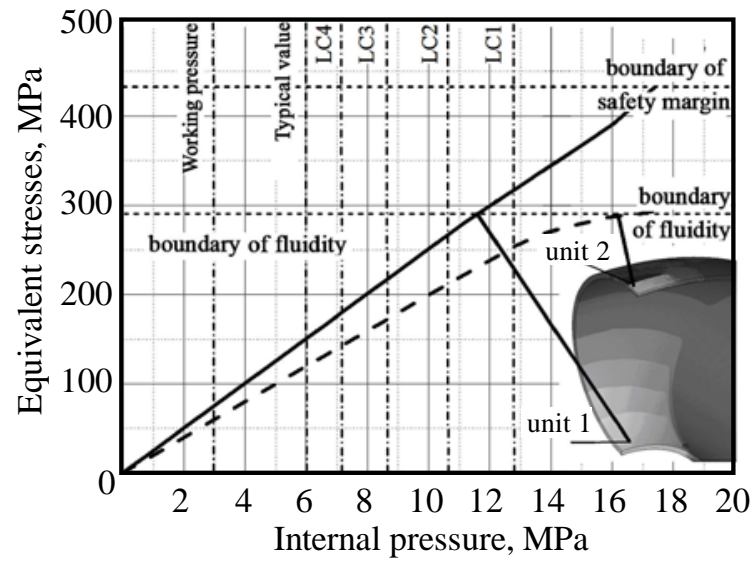

Fig. 6. Change of equivalent stresses in the defective pipeline's elbow after 10 years of operation at different values of internal pressure

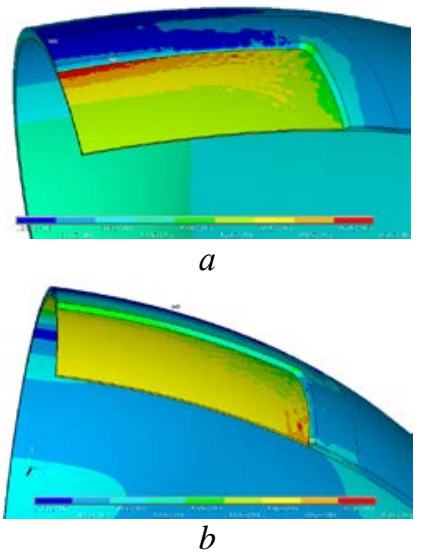

Fig. 8. Distribution of equivalent stress in the case of plastic deformations in a defective pipeline| after 42 (a) and 45 (b) years of operation

If by this time deformation was observed in the longitudinal direction of the defect (Fig. 8, a), then from the 45th year it appear in the transverse direction, as shown in Fig. 8, $b$.

Summarizing the results of the calculations, they can be reflected as a change in the value of internal pressure, which leads to the appearance of plastic deformation during the 45-year operation of the pipeline (Fig. 9).

In Fig. 9, the line with rectangular markers reflects a change in the value of the internal pressure, depending on the size of the defect what occurs the plastic deformation. The straight lines indicate the maximum external load, depending on the location of the pipeline.

From the analysis of the result, it can be seen that during the exploitation period up to 19 years the pipeline does not withstand the maximum load in the LC1 and LC2 zones. That is at the value of the load of more than 8.6 MPa in the pipeline irreversible plastic deformations arise.

Found that in the period after 30 years of operation in the pipeline there are irreversible plastic deformations at maximum load, even in the LC4 zone. In the period from 35 to 40 years, a relatively small change in the marginal load was detected (by $7.5 \%$ ). In the period from 40 to 45 years, the marginal load drops sharply by almost $50 \%$.) 
The graph shows that the construction with the corresponding defects does not withstand the maximum load in any zone. But plastic deformations at nominal pressure arise only from the age of 44 years, which suggests that the operation of the pipeline for more than 40 years is unacceptable.

In addition, it should be noted that during the exploitation period of 37 years the pipeline with the corresponding defect does not withstand the maximum load in the corresponding areas (Fig. 9).

Conclusions Calculations have been made to determine the residual strength of the main pipeline with increasing surface defect during the operation period from 10 to 45 years. To solve the problems, a parametric model of the pipeline with a threedimensional surface defect whose geometric dimensions change over time was developed. For the modeling of the growth of damage, a step-by-step law was used. After

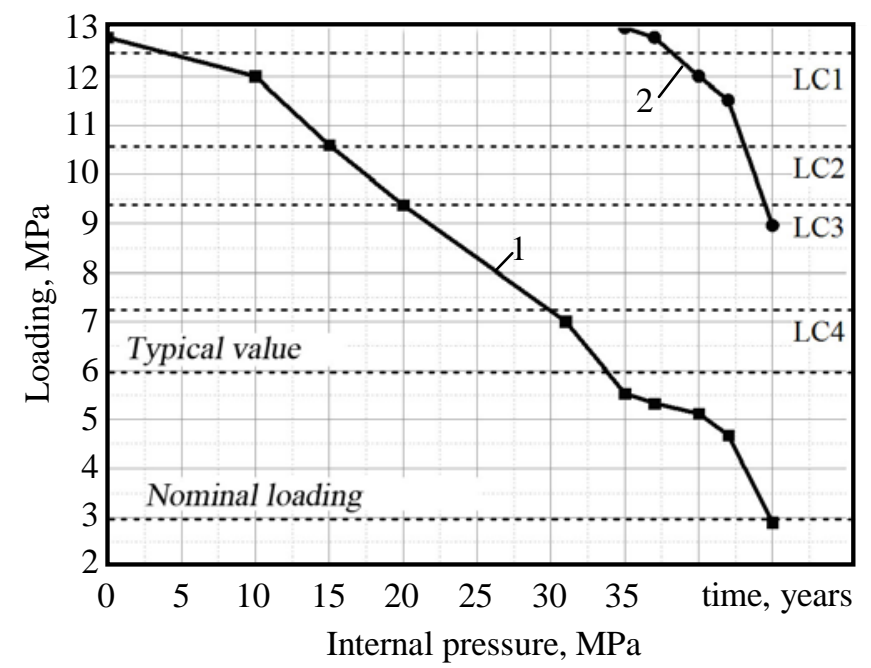

Fig. 9. The value of internal pressure, which leads to the appearance of plastic deformation in the construction and achievement of the boundary of strength: 1 - appearance of plastic deformations; 2 - equivalent stresses reach the boundary of strength analyzing the results, we can conclude that during prolonged operation (over 40 years) the pipeline loses its strength and may collapse even at nominal loads. It should be also note that during the period of operation over 45 years the zone of occurrence of plastic deformations in the damage is changing and distribution is not in the longitudinal direction, as in all preceding cases, but in the transverse. In the case of operation from 37 to 45 years, with the maximum possible load in the zones LC1, LC2, LC3 pipeline is losing its strength.

\section{Література}

1. Valor A., Caleyo F., Hallen J. M., Velázquez J.C. Reliability assessment of buried pipelines based on different corrosion rate models. Corrosion Science, 2013. Vol. 66. P. 78-87. DOI: 10.1016/j.corsci.2012.09.005

2. Caleyo F., Velázquez J.C., Valor A., Hallen J.M. Probability distribution of pitting corrosion depth and rate in underground pipelines : a monte carlo study. Corrosion Science. 2009. Vol. 51, No. 9. P. 19251934. DOI: $10.1016 /$ j.corsci.2009.05.019

3. Ждек А.Я., Груз В.Я. Визначення залишкового ресурсу тривало експлуатованих нафтопроводів із врахування неявних корозійних дефектів та умов експлуатації. Науковий вісник ІФНТУНГ, 2013. Вип. №2(32). С. 132-135.

4. Ma B., Shuai J., Liu D., Xu K. Assessment on failure pressure of high strength pipeline with corrosion defects. Engineering Failure Analysis. 2013. Vol. 32. P. 209-219. DOI: 10.1016/j.engfailanal.2013.03.015

5. Li X., Bai Y., Su C., Li M. Effect of interaction between corrosion defects on failure pressure of thin wall steel pipeline. International Journal of Pressure Vessels and Piping. 2016. 138. P. 8-18. DOI: 10.1016/j.ijpvp.2016.01.002

6. Han Y-L, Shen S-M., Dai S-H. Artificial neural network technology as a method to evaluate the failure bending moment of a pipe with a circumferential crack. International Journal of Pressure Vessels and Piping. 1996. Vol. 0161, No. 95. P. 1-6. DOI: 10.1016/0308-0161(95)00033-X

7. Fekete G., Varga L. The effect of the width to length ratios of corrosion defects on the burst pressures of transmission pipelines. Engineering Failure Analysis. 2012. Vol. 21. P. 21-30. DOI: 10.1016/j.engfailanal.2011.12.002 
8. Silva R.C.C., Guerreiro J.N.C., Loula A.F.D.A study of pipe interacting corrosion defects using the fem and neural networks. Advances in Engineering Software. 2007. Vol. 38. P. 868-875. DOI: 10.1016/j.advengsoft.2006.08.047

9. Al-Owaisi S.S., Becker A.A., Sun W. Analysis of shape and location effects of closely spaced metal loss defects in pressurised pipes. Engineering Failure Analysis. 2016. P. 22. DOI: 10.1016/j.engfailanal.2016.04.032

10. Bedairi B., Cronin D., Hosseini A., Plumtree A. Failure prediction for crack-in-corrosion defects in natural gas transmission pipelines. International Journal of Pressure Vessels and Piping. 2012. Vol. 9697. P. 90-99. DOI: 10.1016/j.ijpvp.2012.06.002

11. Chen Y., Zhang H., Zhang J. et al. Failure assessment of x80 pipeline with interacting corrosion defects. Engineering Failure Analysis. 2015. Vol. 47. P. 67-76. DOI: 10.1016/ j.engfailanal.2014.09.013

12. Filho J.E.A., Machado R.D., Bertin R.J., Valentini M.D. On the failure pressure of pipelines containing wall reduction and isolated pit corrosion defects. Computers and Structures. 2014. Vol. 132. P. 22-33. DOI: 10.1016/j.compstruc.2013.10.017

13. Cunha, D. J. S., Benjamin, A. C., Silva, R. C. C., Guerreiro, J. N. C., Drach, P. R. C. Fatigue analysis of corroded pipelines subjected to pressure and temperature loadings. International Journal of Pressure Vessels and Piping. 2014. 113, P. 15-24. DOI: 10.1016/j.ijpvp.2013.10.013

14. Netto T.A., Ferraz U.S., Botto A. On the effect of corrosion defects on the collapse pressure of pipelines. International Journal of Solids and Structures. 2007. Vol. 44. P. 7597-7614. DOI: 10.1016/j.ijsolstr.2007.04.028

15. Mirchev Y.N, Larin O., Potopalska K. Investigation of influence of the repair bandage on the stressstrain state of the pipeline elbow with VSD. NDT days 2016. “Дни на безразрушителния контрол 2016”. 2016. № 1 (187). P. 411-414.

\section{References}

1. Valor, A., Caleyo, F., Hallen, J. M., \& Velázquez, J. C. (2013). Reliability assessment of buried pipelines based on different corrosion rate models. Corrosion Science, 66, 78-87. DOI: 10.1016/j.corsci.2012.09.005

2. Caleyo, F., Velázquez, J C., Valor, A., \& Hallen, J.M. (2009). Probability distribution of pitting corrosion depth and rate in underground pipelines: A Monte Carlo study. Corrosion Science, 51(9), 19251934. DOI: $10.1016 /$ j.corsci.2009.05.019

3. Zhdek, A.Ya., Gruz, V.Ya. (2013). Determination of residual life long oil pipeline operated by subject available corrosion defects and conditions of use. Naukoviy visnik IFNTUNG, №2(32), 132-135.

4. Ma, B., Shuai, J., Liu, D., \& Xu, K. (2013). Assessment on failure pressure of high strength pipeline with corrosion defects. Engineering Failure Analysis, 32, 209-219. DOI: 10.1016/j.engfailanal.2013.03.015

5. Li, X., Bai, Y., Su, C., \& Li, M. (2016). Effect of interaction between corrosion defects on failure pressure of thin wall steel pipeline. International Journal of Pressure Vessels and Piping, 138, 8-18. DOI: 10.1016/j.ijpvp.2016.01.002

6. Han, Y. L., Shen, S. M., \& Dai, S. H. (1996). Artificial neural network technology as a method to evaluate the failure bending moment of a pipe with a circumferential crack. International Journal of Pressure Vessels and Piping, 68(1), 1-6. DOI: 10.1016/0308-0161(95)00033-X

7. Fekete, G., \& Varga, L. (2012). The effect of the width to length ratios of corrosion defects on the burst pressures of transmission pipelines. Engineering Failure Analysis, 21, 21-30. DOI: 10.1016/j.engfailanal.2011.12.002

8. Silva, R.C.C., Guerreiro, J.N.C., \& Loula, A.F.D. (2007). A study of pipe interacting corrosion defects using the FEM and neural networks. Advances in Engineering Software, 38(11-12), 868-875. DOI: 10.1016/j.advengsoft.2006.08.047

9. Al-Owaisi, S.S., Becker, A.A., \& Sun, W. (2016). Analysis of shape and location effects of closely spaced metal loss defects in pressurised pipes. Engineering Failure Analysis, 68, 172-186. DOI: 10.1016/j.engfailanal.2016.04.032

10. Bedairi, B., Cronin, D., Hosseini, A., \& Plumtree, A. (2012). Failure prediction for Crack-in-Corrosion defects in natural gas transmission pipelines. International Journal of Pressure Vessels and Piping, 9697, 90-99. DOI: 10.1016/j.ijpvp.2012.06.002 
11. Chen, Y., Zhang, H., Zhang, J., Liu, X., Li, X., \& Zhou, J. (2015). Failure assessment of X80 pipeline with interacting corrosion defects. Engineering Failure Analysis, 47(PA), 67-76. DOI: 10.1016/j.engfailanal.2014.09.013

12. Abdalla Filho, J. E., Machado, R. D., Bertin, R. J., \& Valentini, M. D. (2014). On the failure pressure of pipelines containing wall reduction and isolated pit corrosion defects. Computers and Structures, 132, 22-33. DOI: 10.1016/j.compstruc.2013.10.017

13. Cunha, D.J.S., Benjamin, A.C., Silva, R.C.C., Guerreiro, J.N.C., Drach, P.R.C. (2014). Fatigue analysis of corroded pipelines subjected to pressure and temperature loadings. International Journal of Pressure Vessels and Piping, 113, pp. 15-24. 2014. DOI: 10.1016/j.ijpvp.2013.10.013

14. Netto, T.A., Ferraz, U.S., \& Botto, A. (2007). On the effect of corrosion defects on the collapse pressure of pipelines. International Journal of Solids and Structures, 44(22-23), 7597-7614. DOI: 10.1016/j.ijsolstr.2007.04.028

15. Mirchev Y.N, Larin O., Potopalska K. (2016) Investigation of influence of the repair bandage on the stress-strain state of the pipeline elbow with VSD. NDT days 2016. Days of Non - destructive Control 2016, № 1 (187). P. 411-414. 